\title{
Article \\ Determination of the Activation Energy for Hydride Decomposition Using a Sieverts-Type Apparatus and the Kissinger Equation
}

\author{
Myoung-Youp Song *(D) and Young-Jun Kwak (D)
}

check for updates

Citation: Song, M.-Y.; Kwak, Y.-J. Determination of the Activation Energy for Hydride Decomposition Using a Sieverts-Type Apparatus and the Kissinger Equation. Metals 2022, 12, 265. https://doi.org/10.3390/ met12020265

Academic Editor: José Machado

Received: 1 December 2021

Accepted: 25 January 2022

Published: 31 January 2022

Publisher's Note: MDPI stays neutral with regard to jurisdictional claims in published maps and institutional affiliations.

Copyright: () 2022 by the authors. Licensee MDPI, Basel, Switzerland. This article is an open access article distributed under the terms and conditions of the Creative Commons Attribution (CC BY) license (https:// creativecommons.org/licenses/by/ $4.0 /)$.
Division of Advanced Materials Engineering, Hydrogen \& Fuel Cell Research Center, Engineering Research Institute, Jeonbuk National University, 567 Baekje-daero, Deokjin-gu, Jeonju 54896, Korea; twistking18@jbnu.ac.kr

* Correspondence: songmy@jbnu.ac.kr; Tel.: +82-10-3260-2379

\begin{abstract}
We developed a method to determine the activation energy for hydride decomposition using a Sieverts-type apparatus and the Kissinger equation, not using thermal analysis methods. The quantity of hydrogen released from the sample and the temperature of the reactor were first measured as a function of time at different heating rates $(\Phi)$ in a Sieverts-type apparatus. The dehydriding rates were calculated according to time and the temperature $T_{\mathrm{m}}$ (at which the dehydriding rate was the highest). $\Phi$ and $T_{\mathrm{m}}$ were then applied to the Kissinger equation. The dehydriding rate of $\mathrm{Mg}-5 \mathrm{Ni}$ samples obeyed a first-order law, and the Kissinger equation could thus be used to determine the activation energy. On a heating rate of $3 \mathrm{~K} / \mathrm{min}$, the decomposition rate of hydride was the highest at $590.0 \mathrm{~K}$. From a plot of $\ln \left(\Phi / T_{\mathrm{m}}{ }^{2}\right)$ versus $1 / T_{\mathrm{m}}$, the obtained activation energy for hydride decomposition was $174 \mathrm{~kJ} /$ mole.
\end{abstract}

Keywords: Mg; hydrogen storage; Sieverts-type apparatus; Kissinger equation; activation energy

\section{Introduction}

Researchers are increasingly interested in hydrogen as a next-generation energy carrier. However, issues surrounding its storage and transportation first need to be addressed. One potential solution is to store hydrogen through metal hydride, which has the advantages of being both compact and safe.

To find the hydride decomposition temperature, the quantity of hydrogen released, and the heat involved in the hydride decomposition, thermal analysis methods-such as thermogravimetric analysis (TGA), differential scanning calorimetry (DSC) analysis, differential thermal analysis (DTA), and thermal desorption spectroscopy (TDS) analysishave been conducted. The data from thermal analysis methods were used to calculate the activation energy for $\mathrm{MgH}_{2}$ decomposition applying the Kissinger equation [1-5].

In this work, we determined the activation energy for hydride decomposition using a Sieverts-type apparatus and the Kissinger equation. This method is supposed to be useful without employing high-quality thermal analysis systems (calorimetric technique apparatuses with high- or ultra-high-vacuum performance and enabling samples to be reloaded without contact with atmosphere). We can perform experiments to obtain activation energy for hydride decomposition at the same apparatus where samples were activated.

Reacted fraction is expressed by $F$ and time by $t$. The rate of reaction $(\mathrm{d} F / \mathrm{d} t)$ is proportional to a function of the amount of reactant $[f(F)]$ :

$$
\mathrm{d} F / \mathrm{d} t=k \mathrm{f}(F) .
$$

A rate constant $k$ in Equation (1) is generally given by the Arrhenius equation:

$$
k=Z \exp (-E / R T)
$$


where $Z$ is a constant, $E$ an activation energy, $R$ the gas constant, and $T$ temperature.

The Kissinger equation is expressed by [6]

$$
\begin{gathered}
\ln \left(\Phi / T_{\mathrm{m}}{ }^{2}\right)=\ln (Z R / E)-E / R T_{\mathrm{m}} \\
\mathrm{d}\left(\ln \left(\Phi / T_{\mathrm{m}}{ }^{2}\right) / \mathrm{d}\left(1 / T_{\mathrm{m}}\right)=-E / R\right.
\end{gathered}
$$

where $\Phi=\mathrm{d} T / \mathrm{d} t$ is the heating rate. $T_{\mathrm{m}}$ is the temperature at which the decomposition rate of hydride $\left(\mathrm{d} H_{\mathrm{d}} / \mathrm{d} t\right)$ has the maximum value. $E$ is the activation energy for hydride decomposition. Here, $H_{\mathrm{d}}$ is the quantity of hydrogen released from the sample. For the derivation of the Kissinger equation, the first-order reaction was assumed [6]. The Kissinger equation can thus be used for the thermal decomposition, which obeys a first-order law: at constant temperature,

$$
\mathrm{d} F / \mathrm{d} t=k(1-F)
$$

where $t$ is time, and $k$ is a rate constant. Integration of this equation becomes

$$
-\ln (1-F)=k t
$$

Mg has many advantages as a hydrogen-storage material, but it has a low dehydriding rate even at $573 \mathrm{~K}$ around. To prepare a sample of $\mathrm{Mg}$ with increased hydriding and dehydriding rates, $\mathrm{Ni}$ was added, considering the reports of many researchers [7-10]. In the present work, Mg-5Ni samples with a composition of $95 \mathrm{wt} \% \mathrm{Mg}+5 \mathrm{wt} \% \mathrm{Ni}$ were prepared by milling in hydrogen atmosphere. We investigated the order of the dehydriding rate of hydrided $\mathrm{Mg}-5 \mathrm{Ni}$; we showed that the dehydriding rate of the $\mathrm{Mg}-5 \mathrm{Ni}$ sample obeys a first-order law and that the Kissinger equation can thus be used to determine the activation energy for hydride decomposition of the hydrided $\mathrm{Mg}-5 \mathrm{Ni}$. To determine the activation energy for hydride decomposition, the quantity of hydrogen released from the sample and the temperature of the reactor were first measured as a function of time at different heating rates $(\Phi)$ in a Sieverts-type apparatus. The dehydriding rates were calculated according to time and the temperature at which the dehydriding rate was the highest $\left(T_{\mathrm{m}}\right)$ was obtained. $\Phi$ and $T_{\mathrm{m}}$ were then applied to the Kissinger equation. As far as we know, the Kissinger method is not applied by using a volumetric technique for determining the activation energy for the dehydrogenation of hydride materials. The Kissinger method is usually applied by using calorimetric techniques.

\section{Materials and Methods}

Mg (-20 + 100 mesh, 99.8\% (metals basis), Alfa Aesar) and Ni (Nickel powder APS, 2.2-3.0 $\mu \mathrm{m}$, purity $99.9 \%$ metal basis, C typically $<0.1 \%$, Alfa Aesar) were used as starting materials.

For the synthesis of $\mathrm{Mg}-5 \mathrm{Ni}$, milling was carried out in a planetary ball mill (Planetary Mono Mill; Pulverisette 6, Fritsch, Idar-Oberstein, Germany). A mixture of Mg and Ni at the weight ratio of 95:5 (total weight $=8 \mathrm{~g}$ ) was mixed in a hermetically sealed stainless steel container (with 105 hardened steel balls, total weight $=360 \mathrm{~g}$ ). The sample to ball weight ratio was 1:45. All sample handling was performed in a glove box under an Ar atmosphere in order to minimize oxidation. The mill container (volume of $250 \mathrm{~mL}$ ) was then filled with high purity hydrogen gas (about 12 bar), which was refilled every $2 \mathrm{~h}$. Milling was performed at the disc revolution speed of $400 \mathrm{rpm}$ for $6 \mathrm{~h}$.

Hydrogen absorption and release of Mg-5Ni were investigated using a Sieverts-type volumetric apparatus, which was described previously [11]. Before hydrogen release measurements, samples were hydrided at $593 \mathrm{~K}$ under $12 \mathrm{bar}_{2}$ for $60 \mathrm{~min}$. The quantity of the hydrogen released under $1.0 \mathrm{bar}_{2}$ and the temperature of the reactor were measured as a function of time as the sample was heated at the heating rates $(\Phi)$ of $3,6,9,12$, and $15 \mathrm{~K} / \mathrm{min}$ to increase the temperature from room temperature up to $673 \mathrm{~K}$. 


\section{Results and Discussion}

Figure 1 shows micrographs captured by SEM at various magnifications of $\mathrm{Mg}-5 \mathrm{Ni}$ dehydrogenated at the eighth cycle. Shapes of particles are irregular. Particle size is not homogeneous. Particles are agglomerated. Quite small particles are on the surfaces of agglomerates.

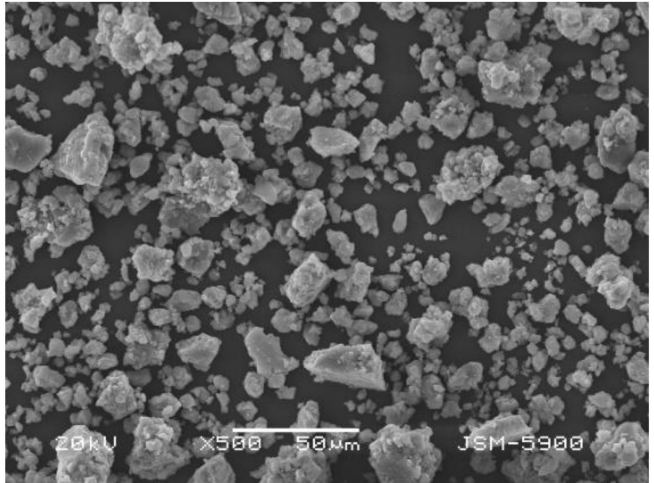

(a)

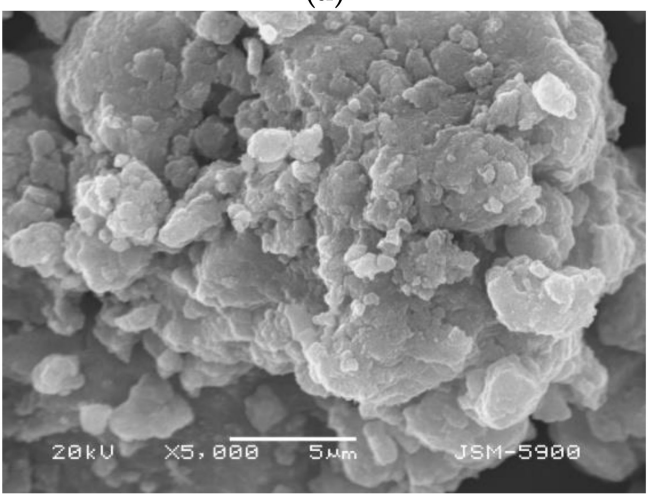

(c)

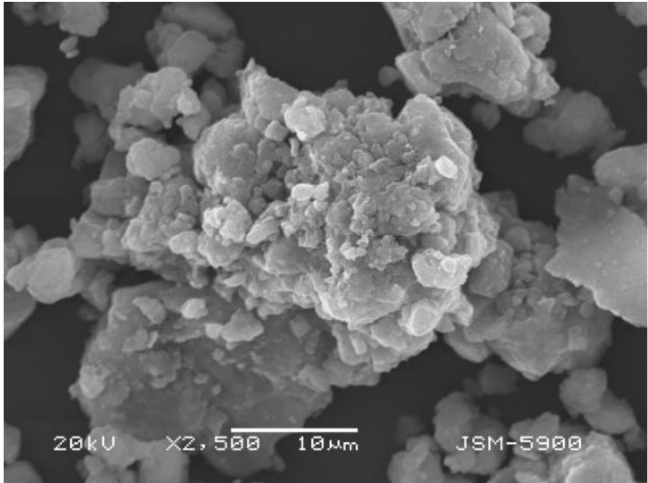

(b)

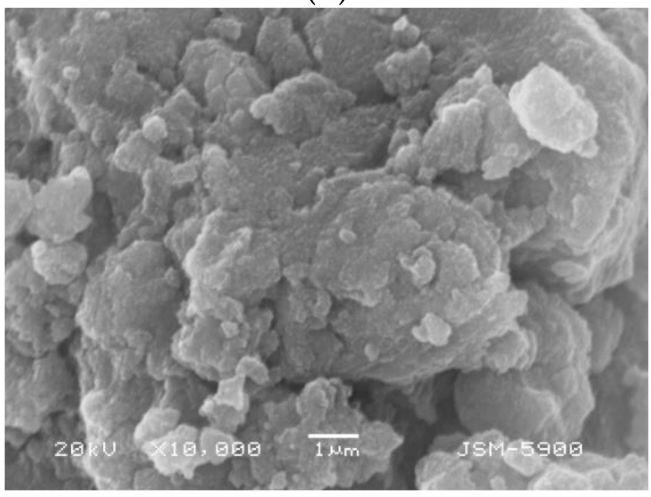

(d)

Figure 1. Micrographs captured by SEM at various magnifications $((\mathbf{a}) \times 500,(\mathbf{b}) \times 2,500,(\mathbf{c}) \times 5000$, and $(\mathbf{d}) \times 10,000)$ of $\mathrm{Mg}-5 \mathrm{Ni}$ dehydrogenated at the eighth cycle.

An X-ray diffractogram of $\mathrm{Mg}-5 \mathrm{Ni}$ dehydrogenated at the eighth cycle is shown in Figure 2. The sample contains $\mathrm{Mg}$ and small amounts of $\beta-\mathrm{MgH}_{2}, \mathrm{Mg}_{2} \mathrm{Ni}$, and $\mathrm{MgO}$. $\mathrm{Mg}_{2} \mathrm{Ni}$ is believed to have been formed during heating at the first cycle [12]. $\mathrm{Mg}$ and $\mathrm{Mg}_{2} \mathrm{Ni}$ absorb hydrogen and then release hydrogen during hydriding-dehydriding cycling at temperatures of the present work.

The quantity of hydrogen released from the sample was expressed by $H_{\mathrm{d}}$ in the unit of $\mathrm{wt} \% \mathrm{H}$, which was defined as the percentage of the released hydrogen on the basis of the sample weight. Variation in the $H_{\mathrm{d}}$ versus $t$ curve with the number of cycles, $n$, at $593 \mathrm{~K}$ under 1.0 bar $\mathrm{H}_{2}$ for hydrided $\mathrm{Mg}-5 \mathrm{Ni}$ is shown in Figure 3. At $n=1$, the initial dehydriding rate is quite high, the dehydriding rate is the highest after about $5 \mathrm{~min}$, and the dehydriding rate becomes low after $20 \mathrm{~min}$. At $n=2$, the initial dehydriding rate and the dehydriding rate after $5 \mathrm{~min}$ are higher than at $n=1$. The $H_{\mathrm{d}}$ versus $t$ curves at $n=2$ and $n=3$ are very similar, showing that the activation of the samples was completed after the first cycle.

Dehydrided fraction was expressed by $F$, which was calculated by dividing $H_{\mathrm{d}}$ by the quantity of hydrogen released completely from the fully hydrided $\mathrm{Mg}-5 \mathrm{Ni}$ sample $(8.07 \mathrm{wt} \% \mathrm{H})$. To check whether the dehydriding reaction of the Mg-5Ni sample obeys a first-order law or not, $-\ln (1-F)$ was plotted against $t$. Figure 4 shows variation of $-\ln (1-F)$ with $t$ at heating rates of 3,6 , and $9 \mathrm{~K} / \mathrm{min}$ at $593 \mathrm{~K}$ under 1.0 bar $\mathrm{H}_{2}$ for hydrided Mg-5Ni and variation of $-\ln (1-F)$ with $t$ in the range where most of the 
hydrogen absorbed during hydriding is released. Figure 4a shows that in the beginning $-\ln (1-F)$ is small, then increases very rapidly, and finally increases very slowly. Figure $4 \mathrm{~b}$ shows that $-\ln (1-F)$ versus $t$ plots exhibit good linearity. The good linearity of these plots supports that the dehydriding rate of the $\mathrm{Mg}-5 \mathrm{Ni}$ sample obeys a first-order law and that the Kissinger equation can thus be used to determine the activation energy for hydride decomposition of the hydrided $\mathrm{Mg}-5 \mathrm{Ni}$.

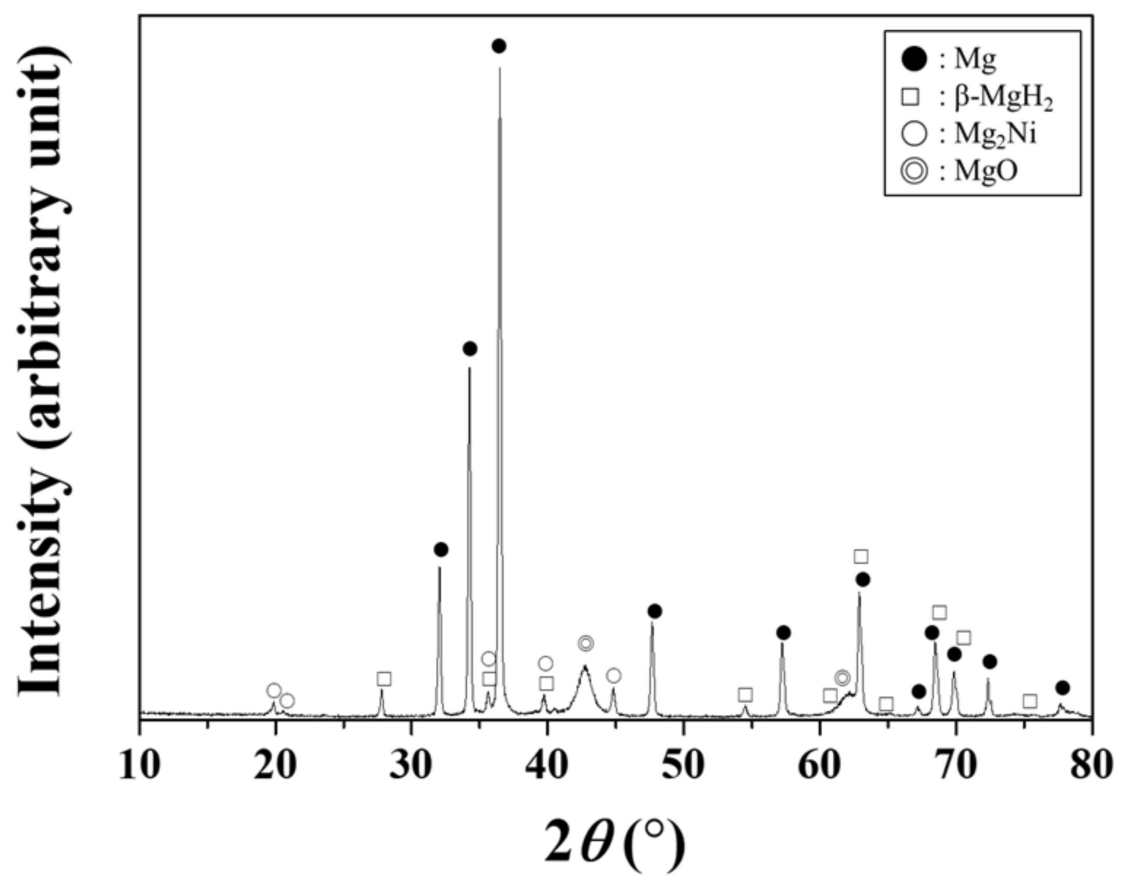

Figure 2. X-ray diffractogram of Mg-5Ni dehydrogenated at the eighth cycle.

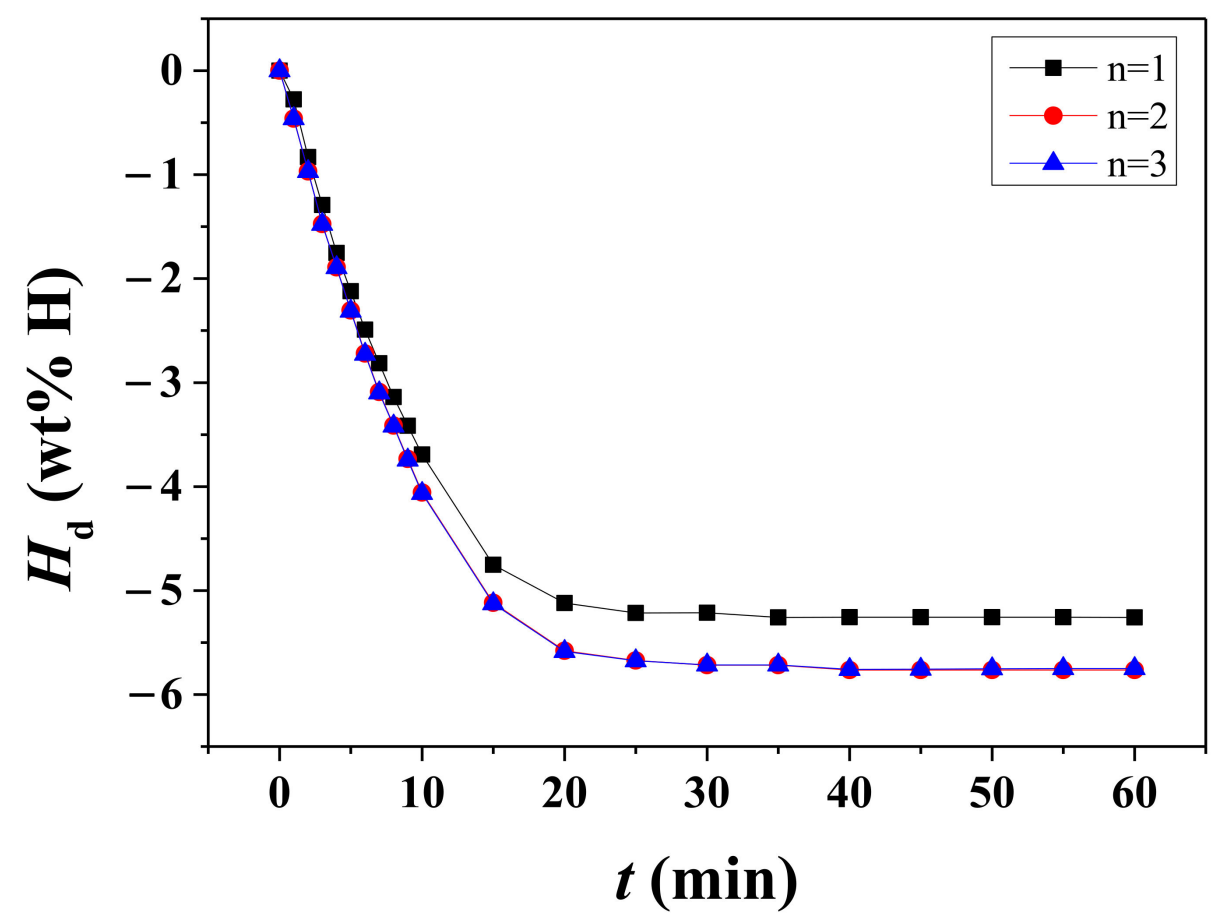

Figure 3. Variation in the $H_{\mathrm{d}}$ versus $t$ curve with the number of cycles, $n$, at $593 \mathrm{~K}$ under 1.0 bar $\mathrm{H}_{2}$ for hydrided Mg-5Ni. 


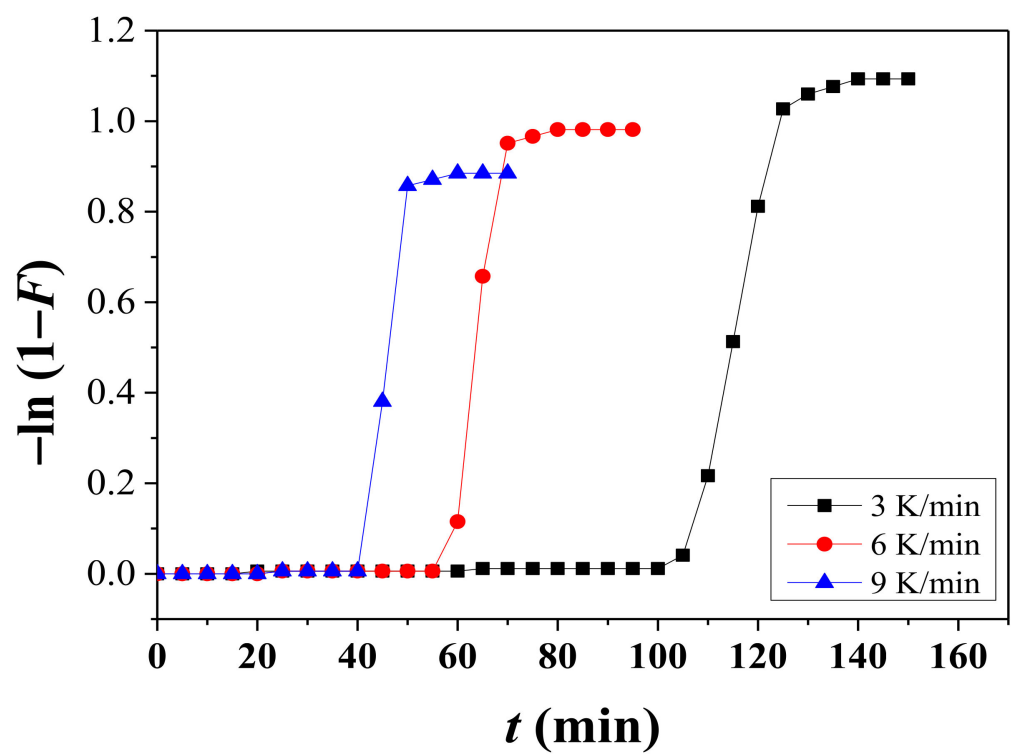

(a)

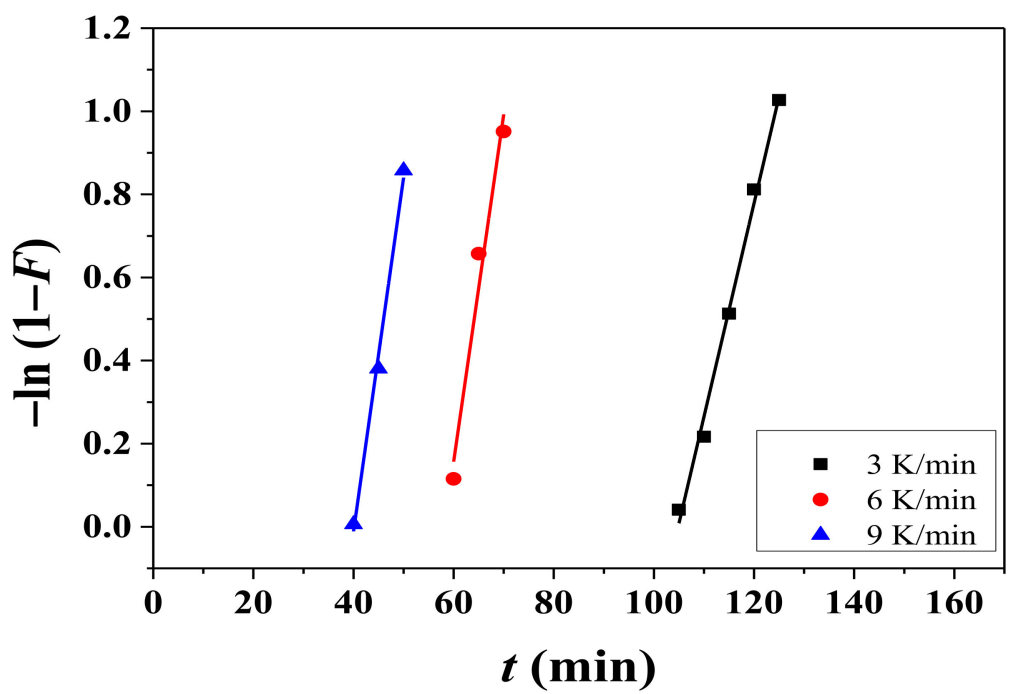

(b)

Figure 4. (a) Variations in $-\ln (1-F)$ with $t$ at heating rates of 3,6 , and $9 \mathrm{~K} / \mathrm{min}$ at $593 \mathrm{~K}$ under 1.0 bar $\mathrm{H}_{2}$ for hydrided $\mathrm{Mg}-5 \mathrm{Ni}$ and $(\mathbf{b})$ variation in $-\ln (1-F)$ with $t$ in the range where most of the hydrogen absorbed during hydriding is released.

To determine the onset temperature and the temperature at which the dehydriding rate was the highest $\left(T_{\mathrm{m}}\right)$ for hydride decomposition of hydrided $\mathrm{Mg}-5 \mathrm{Ni}$ and to calculate the activation energy for hydride decomposition of hydrided $\mathrm{Mg}-5 \mathrm{Ni}$ applying the Kissinger equation, variations in the released hydrogen quantity, $H_{\mathrm{d}}$, with time, $t$, were obtained after activation at $n=4-8$.

Variations in $H_{\mathrm{d}}$ and temperature $T$ with $t$ under 1.0 bar $\mathrm{H}_{2}$ for hydrided $\mathrm{Mg}-5 \mathrm{Ni}$ are shown in Figure 5. The sample was heated with a heating rate of $3 \mathrm{~K} / \mathrm{min}$. As the time elapses, the temperature increases and thus the rate of $H_{\mathrm{d}}$ change, $\mathrm{d} H_{\mathrm{d}} / \mathrm{d} t$, will increase. The sample begins to release hydrogen at $572.1 \mathrm{~K}(6060 \mathrm{~s})$, releases hydrogen most rapidly at $590.0 \mathrm{~K}(6780 \mathrm{~s})$, and releases hydrogen very slowly above $640 \mathrm{~K}(7500 \mathrm{~s})$. Correspondingly, the rate of $H_{\mathrm{d}}$ change, $\mathrm{d} H_{\mathrm{d}} / \mathrm{d} t$, is the highest at $590.0 \mathrm{~K}$. In a part of the $T$ versus $t$ curve, a plateau appears. This plateau is believed to indicate the temperature $T_{\mathrm{m}}$ at which the $\mathrm{d} H_{\mathrm{d}} / \mathrm{d} t$ is the highest under 1.0 bar $\mathrm{H}_{2}$ for hydrided $\mathrm{Mg}-5 \mathrm{Ni}$. 


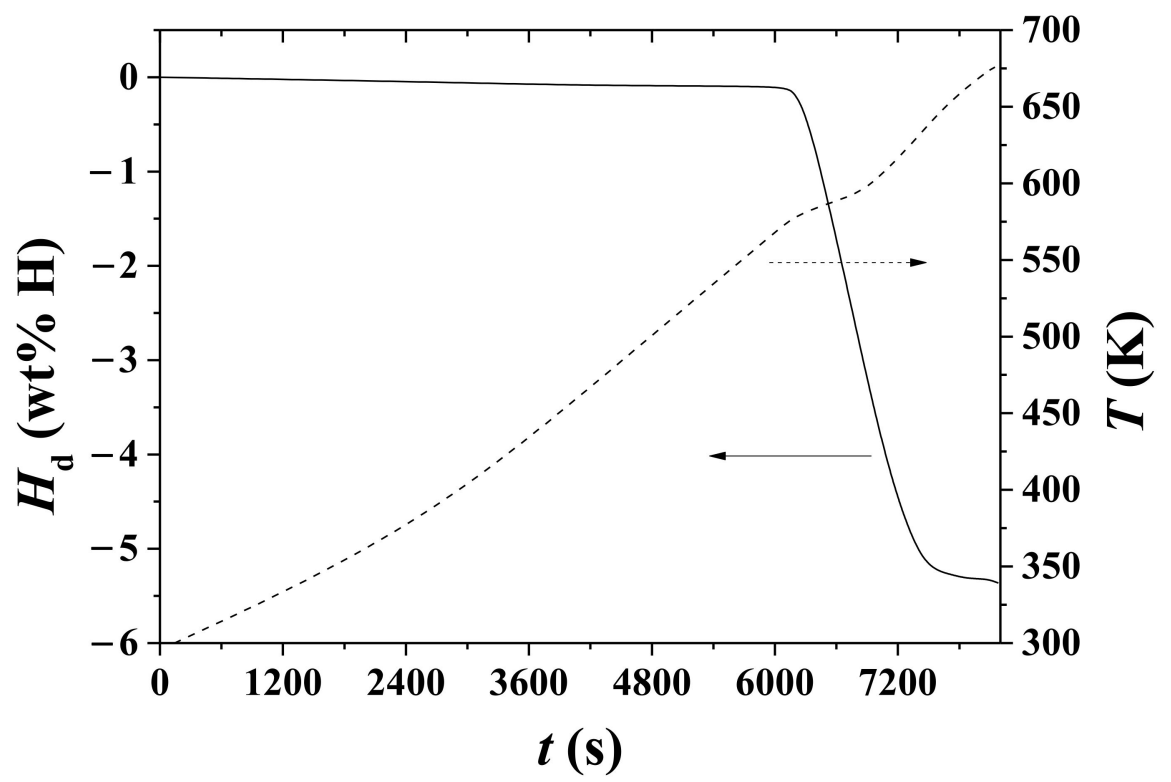

Figure 5. Variations in $H_{\mathrm{d}}$ and temperature $T$ with $t$ under 1.0 bar $\mathrm{H}_{2}$ for hydrided $\mathrm{Mg}-5 \mathrm{Ni}$. The sample was heated with a heating rate of $3 \mathrm{~K} / \mathrm{min}$.

Variations in $H_{\mathrm{d}}$ and temperature $T$ with $\mathrm{t}$ under 1.0 bar $\mathrm{H}_{2}$ for hydrided $\mathrm{Mg}-5 \mathrm{Ni}$ are shown in Figure 6. The sample was heated with a heating rate of $9 \mathrm{~K} / \mathrm{min}$. The sample begins to release hydrogen at $586.6 \mathrm{~K}(2441 \mathrm{~s})$, releases hydrogen most rapidly at $606.3 \mathrm{~K}$ (2570 s), and releases hydrogen very slowly above $650 \mathrm{~K}$ (2921 s). Correspondingly, the rate of $H_{\mathrm{d}}$ change, $\mathrm{d} H_{\mathrm{d}} / \mathrm{d} t$, is the highest at $606.3 \mathrm{~K}$.

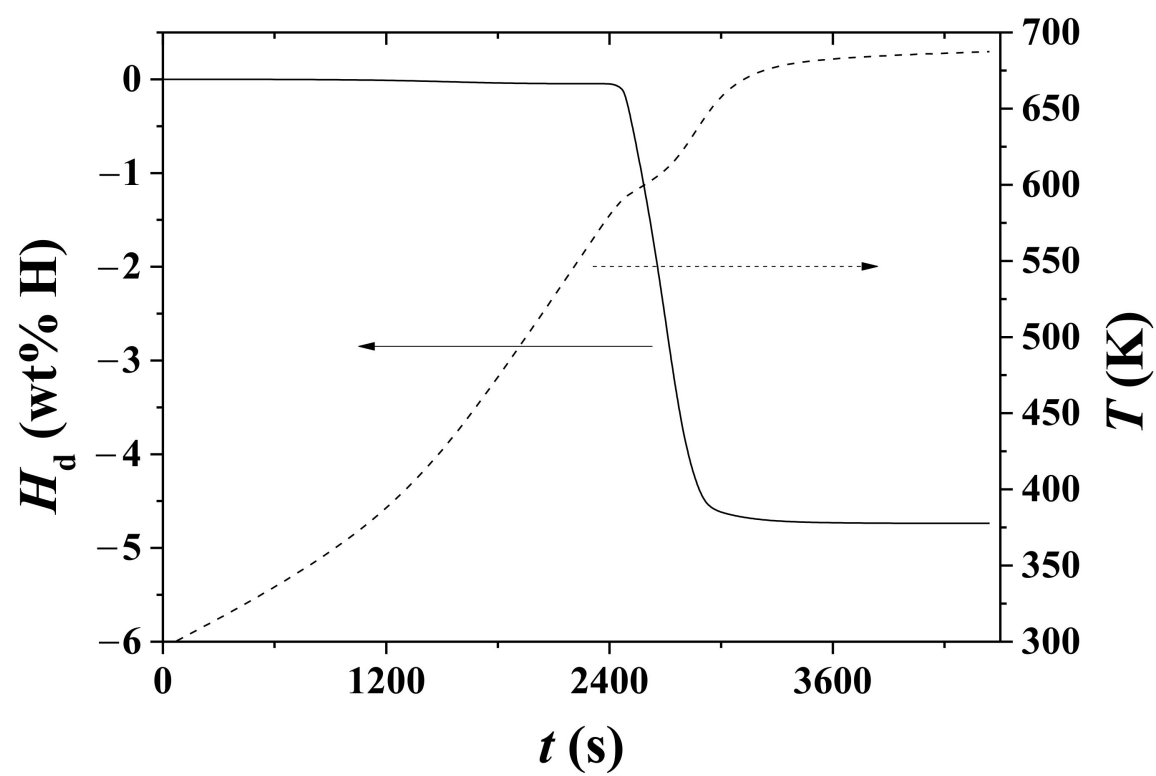

Figure 6. Variations in $H_{\mathrm{d}}$ and $T$ with $t$ under 1.0 bar $\mathrm{H}_{2}$ for hydrided $\mathrm{Mg}-5 \mathrm{Ni}$. The sample was heated with a heating rate of $9 \mathrm{~K} / \mathrm{min}$.

Figure 7 shows variations with time, $t$, of the temperature, $T$, and the rate of $H_{\mathrm{d}}$ change, $\mathrm{d} H_{\mathrm{d}} / \mathrm{d} t$, under 1.0 bar $\mathrm{H}_{2}$ for hydrided $\mathrm{Mg}-5 \mathrm{Ni}$. The sample was heated with a heating rate of $3 \mathrm{~K} / \mathrm{min}$. The temperature increases as time elapses and a plateau appears after about $6780 \mathrm{~s}$. The rate of $H_{\mathrm{d}}$ change begins to increase after $6060 \mathrm{~s}(572.1 \mathrm{~K})$ and becomes very low after $7500 \mathrm{~s}$. The rate of $H_{\mathrm{d}}$ change, $\mathrm{d} H_{\mathrm{d}} / \mathrm{d} t$, is the highest at $6780 \mathrm{~s}(590.0 \mathrm{~K})$. 


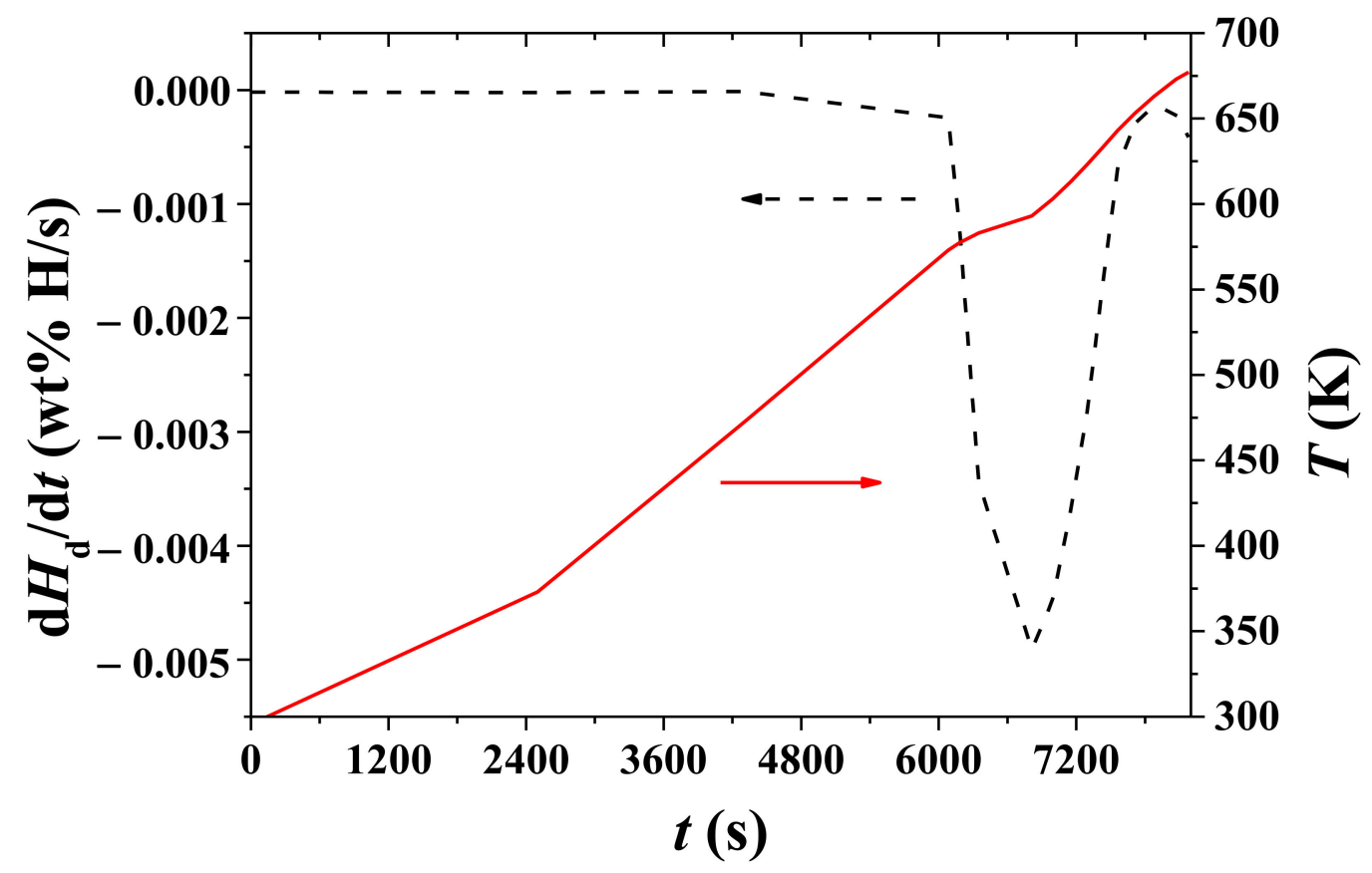

Figure 7. Variations with time, $t$, of temperature, $T$, and the rate of $H_{\mathrm{d}}$ change, $\mathrm{d} H_{\mathrm{d}} / \mathrm{d} t$, under 1.0 bar $\mathrm{H}_{2}$ for hydrided $\mathrm{Mg}-5 \mathrm{Ni}$. The sample was heated with a heating rate of $3 \mathrm{~K} / \mathrm{min}$.

Figure 8 shows variations with time, $\mathrm{t}$, of $\mathrm{T}$ and the $\mathrm{d} H_{\mathrm{d}} / \mathrm{d} t$ under 1.0 bar $\mathrm{H}_{2}$ for hydrided $\mathrm{Mg}-5 \mathrm{Ni}$. The sample was heated with a heating rate of $9 \mathrm{~K} / \mathrm{min}$. As time elapses, the temperature increases, and a plateau appears after about $2570 \mathrm{~s}$. After $3400 \mathrm{~s}$, the temperature increases very slowly. The rate of $H_{\mathrm{d}}$ change begins to increase after $2441 \mathrm{~s}$ $(586.6 \mathrm{~K})$ and becomes very low after $3400 \mathrm{~s}$. The rate of $H_{\mathrm{d}}$ change, $\mathrm{d} H_{\mathrm{d}} / \mathrm{d} t$, is the highest at $2570 \mathrm{~s}(606.3 \mathrm{~K})$.

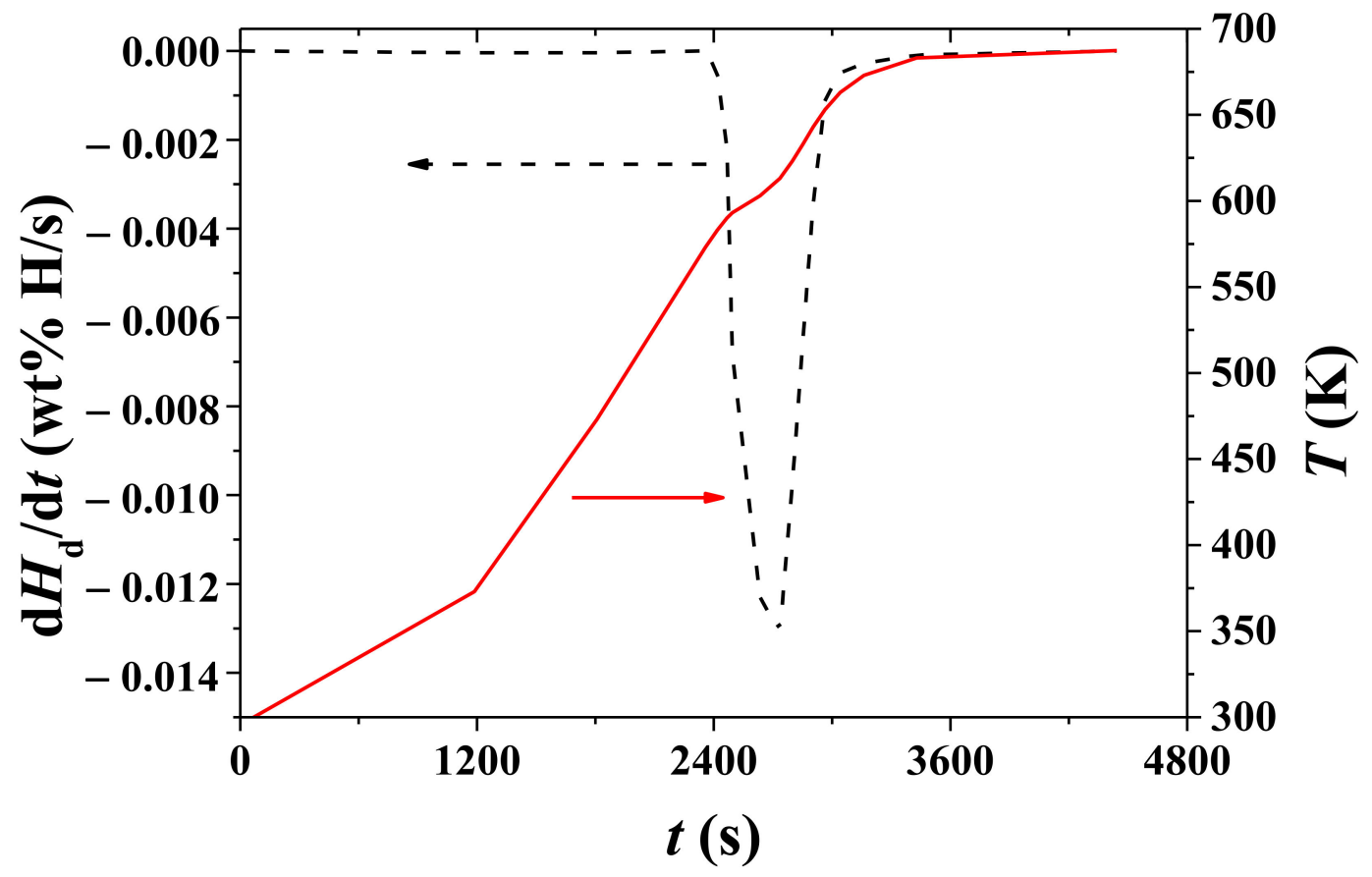

Figure 8. Variations with $t$ of $T$ and $\mathrm{d} H_{\mathrm{d}} / \mathrm{d} t$ under 1.0 bar $\mathrm{H}_{2}$ for hydrided $\mathrm{Mg}-5 \mathrm{Ni}$. The sample was heated with a heating rate of $9 \mathrm{~K} / \mathrm{min}$. 
Table 1 presents variations, with heating rate, in the onset time, onset temperature, and time $t_{\mathrm{m}}$ and temperature $T_{\mathrm{m}}$ at which the $\mathrm{d} H_{\mathrm{d}} / \mathrm{d} t$ has the maximum value under 1.0 bar $\mathrm{H}_{2}$ for hydrided $\mathrm{Mg}-5 \mathrm{Ni}$.

Table 1. Variations, with heating rate $\Phi$, in the onset time, onset temperature, and time $t_{\mathrm{m}}$ and temperature $T_{\mathrm{m}}$ at which the $\mathrm{d} H_{\mathrm{d}} / \mathrm{d} t$ has the maximum value under 1.0 bar $\mathrm{H}_{2}$ for hydrided $\mathrm{Mg}-5 \mathrm{Ni}$.

\begin{tabular}{ccccc}
\hline Heating Rate $\boldsymbol{\Phi}(\mathbf{K} / \mathbf{m i n})$ & Onset Time (s) & Onset Temperature (K) & $\boldsymbol{t}_{\mathbf{m}}(\mathbf{s})$ & $\boldsymbol{T}_{\mathbf{m}}(\mathbf{K})$ \\
\hline 3 & 6060 & 572.1 & 6780 & 590.0 \\
6 & 3327 & 573.6 & 2510 & 596.3 \\
9 & 2441 & 586.6 & 2570 & 606.3 \\
12 & 1931 & 588.8 & 2180 & 612.5 \\
15 & 1589 & 590.0 & 1856 & 613.0 \\
\hline
\end{tabular}

Table 2 presents variations in $T_{\mathrm{m}}, \ln \left(\Phi / T_{\mathrm{m}}{ }^{2}\right)$, and $1 / T_{\mathrm{m}}$, with heating rate $\Phi$ under 1.0 bar $\mathrm{H}_{2}$ for hydrided $\mathrm{Mg}-5 \mathrm{Ni}$.

Table 2. Variations in $T_{\mathrm{m}}, \ln \left(\Phi / T_{\mathrm{m}}{ }^{2}\right)$, and $1 / T_{\mathrm{m}}$, with heating rate $\Phi$ under 1.0 bar $\mathrm{H}_{2}$ for hydrided $\mathrm{Mg}-5 \mathrm{Ni}$.

\begin{tabular}{cccc}
\hline Heating Rate $\boldsymbol{\Phi}(\mathbf{K} / \mathbf{m i n})$ & $\boldsymbol{T}_{\mathbf{m}}(\mathbf{K})$ & $\ln \left(\boldsymbol{\Phi} / \boldsymbol{T}_{\mathbf{m}}{ }^{2}\right)$ & $\mathbf{1} / \boldsymbol{T}_{\mathbf{m}}$ \\
\hline 3 & 590.0 & -11.6616 & 0.001695 \\
6 & 596.3 & -10.9896 & 0.001677 \\
9 & 606.3 & -10.6174 & 0.001649 \\
12 & 612.5 & -10.3502 & 0.001633 \\
15 & 613.0 & -10.1287 & 0.001631 \\
\hline
\end{tabular}

Figure 9 shows a plot of $\ln \left(\Phi / T_{\mathrm{m}}{ }^{2}\right)$ versus $1 / T_{\mathrm{m}}$. The linearity of the plot is good (correlation coefficient: 0.977 ). From this plot, the activation energy for hydride decomposition, $E$, was calculated as $174 \pm 5 \mathrm{~kJ} /$ mole.

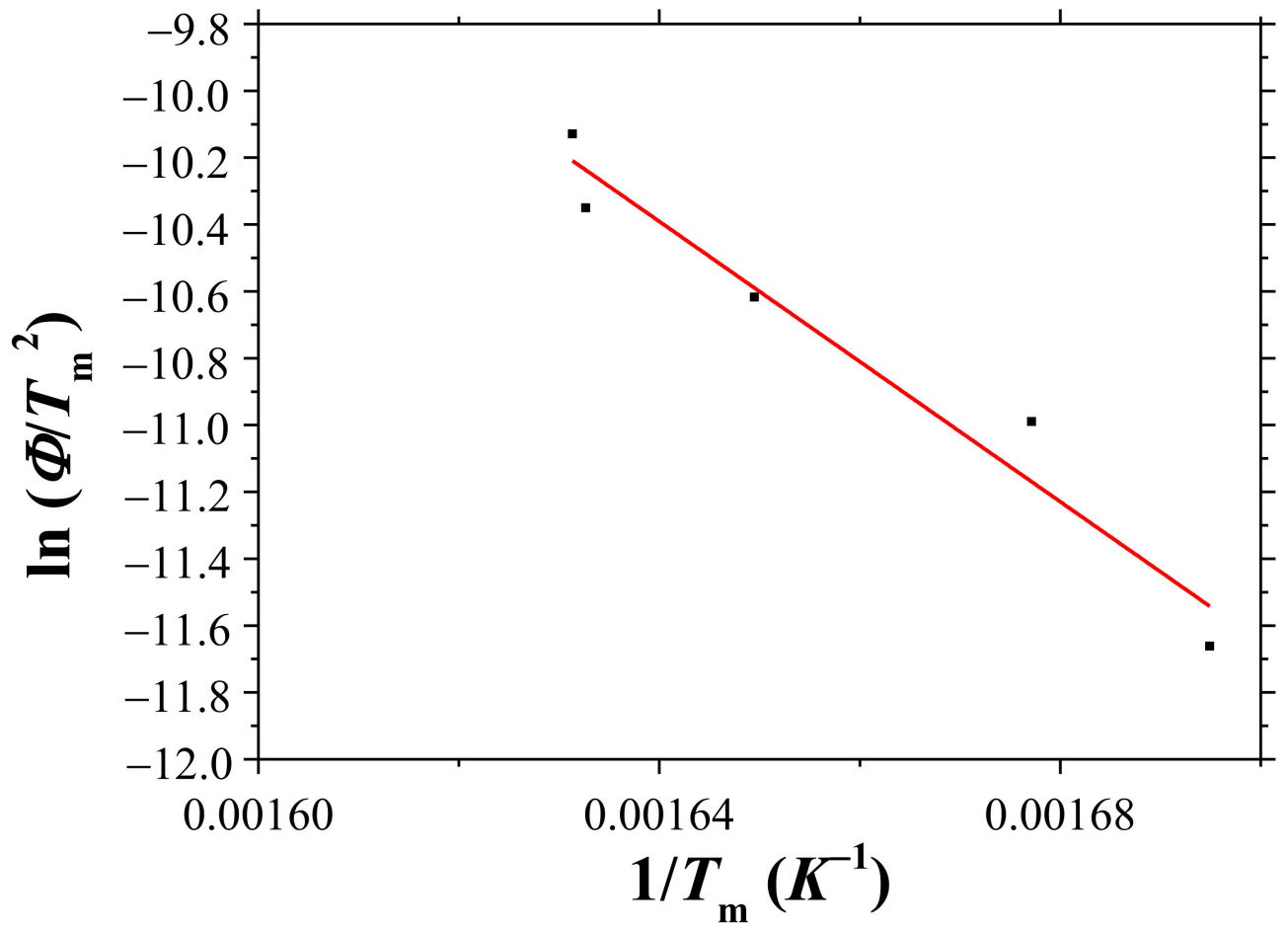

Figure 9. Plot of $\ln \left(\Phi / T_{\mathrm{m}}{ }^{2}\right)$ versus $1 / T_{\mathrm{m}}$. 
Comparing the equation obtained from Figure 9 with Equation (3), $E$ was $174 \pm 5 \mathrm{~kJ} / \mathrm{mole}$, and $Z$ was $5.49 \times 10^{14}$. And thus

$$
k=\left(5.49 \times 10^{14}\right) \exp [-174 \pm 5(\mathrm{~kJ} / \mathrm{mole}) / R T] .
$$

Consequently, the rate equation is given by

$$
\mathrm{d} F / \mathrm{d} t=\left(5.49 \times 10^{14}\right)(1-F) \exp [-174 \pm 5(\mathrm{~kJ} / \mathrm{mole}) / R T] .
$$

Zhao-Karger et al. [1] prepared an infiltrated $\mathrm{MgH}_{2} / \mathrm{ACF}$ (activated carbon fiber) composite by direct hydrogenation of $\mathrm{Bu}_{2} \mathrm{Mg}$ inside the voids of the carbon scaffolds. They also ball-milled and catalyzed a commercial $\mathrm{MgH}_{2}$ with graphite. They performed thermal analysis using high pressure DSC and simultaneous TGA-DSC-MS (mass spectrometry). They reported that the Kissinger plots showed that the activation energies for $\mathrm{MgH}_{2}$ decomposition of the commercial $\mathrm{MgH}_{2}$, the ball-milled $\mathrm{MgH}_{2}$ with graphite, and the infiltrated $\mathrm{MgH}_{2} / \mathrm{ACF}$ composite were 195, 165, and $143 \mathrm{KJ} / \mathrm{mol}$, respectively [1]. Sabitu et al. [2] prepared $\mathrm{MgH}_{2}+4 \mathrm{~mol} \% \mathrm{MO}\left(\mathrm{MO}=\mathrm{Nb}_{2} \mathrm{O}_{5}, \mathrm{Fe}_{3} \mathrm{O}_{4}, \mathrm{ZrO}_{2}\right.$, and $\left.\mathrm{CeO}_{2}\right)$ by ball milling. $\mathrm{MgH}_{2}+4 \mathrm{~mol} \% \mathrm{Nb}_{2} \mathrm{O}_{5}$ had the highest dehydriding rate, followed in order by $\mathrm{MgH}_{2}+4 \mathrm{~mol} \% \mathrm{Fe}_{3} \mathrm{O}_{4}, \mathrm{MgH}_{2}+4 \mathrm{~mol} \% \mathrm{ZrO}_{2}, \mathrm{MgH}_{2}+4 \mathrm{~mol} \% \mathrm{CeO}_{2}$, and $\mathrm{MgH}_{2}$ (without oxide). The Kissinger plots, obtained from TG/DTA data, showed that the activation energies for $\mathrm{MgH}_{2}$ decomposition of $\mathrm{MgH}_{2}+4 \mathrm{~mol} \% \mathrm{MO}\left(\mathrm{MO}=\mathrm{Nb}_{2} \mathrm{O}_{5}, \mathrm{Fe}_{3} \mathrm{O}_{4}, \mathrm{ZrO}_{2}\right.$, and $\mathrm{CeO}_{2}$ ) and $\mathrm{MgH}_{2}$ (without oxide) were 95, 108, 113, 140, and $174 \mathrm{KJ} / \mathrm{mol}$, respectively [2]. The order of the activation energies for $\mathrm{MgH}_{2}$ decomposition of these samples is exactly opposite to that of the dehydriding rates of these samples. The results of Sabitu et al. [2] prove that the main role of oxide additives on increasing the dehydriding rates of $\mathrm{MgH}_{2}$ is lowering the activation energy of $\mathrm{MgH}_{2}$ decomposition. The effects of addition by mechanical milling in hydrogen are reportedly creating defects, producing cracks and clean surfaces, and decreasing particle size [10,13-15]. Figen et al. [3] synthesized $\mathrm{MgH}_{2}$ from modified waste magnesium chips (WMC), which was prepared by mechanically milling waste magnesium with tetrahydrofuran (THF) and $\mathrm{NaCl}$. They performed thermal analysis using DSC. Doyle and Kissinger non-isothermal kinetic models were applied to calculate desorption activation energies, which were found equal to $255 \mathrm{~kJ} / \mathrm{mol}$ and $256 \mathrm{~kJ} / \mathrm{mol}$, respectively [3]. Xiao et al. [4] reported that the Kissinger plots showed that the activation energies for $\mathrm{MgH}_{2}$ decomposition of an as-received $\mathrm{MgH}_{2}$, a ball-milled $\mathrm{MgH}_{2}$, and a ball-milled $\mathrm{MgH}_{2} / \mathrm{LiCl}$ mixture after treatment with tetrahydrofuran (THF) were 213,138 , and $115 \mathrm{KJ} / \mathrm{mol}$, respectively. Xiao et al. [4] performed thermal analysis using TG-DTA [4]. Mustafa et al. [5] studied the effect of $\mathrm{PdCl}_{2}$ on the hydrogen storage properties of $\mathrm{MgH}_{2}$. They reported that, from the Kissinger analysis applied to data obtained by DSC, the apparent activation energy for hydrogen desorption was reduced from $142 \mathrm{~kJ} / \mathrm{mol}$ for as-milled $\mathrm{MgH}_{2}$ to $99 \mathrm{~kJ} / \mathrm{mol}$ after the addition of $20 \mathrm{wt} \% \mathrm{PdCl}_{2}$ [5]. Campostrini et al. [16] investigated the thermal desorption of hydrogen from commercial $\mathrm{MgH}_{2}$ powders by coupled thermogravimetry and mass spectroscopy (TG-MS). They reported that, considering temperatures corresponding to iso-conversion points of transformed fraction $=0.25$ and calculating the relative values of the reaction rate, an activation energy for the hydrogen release of $240 \mathrm{~kJ} / \mathrm{mol}$ was obtained via Friedman method [16]. Table 3 presents the activation energies of reported $\mathrm{Mg}$-based hydrogen storage materials.

The activation energy for hydride decomposition $(174 \mathrm{~kJ} /$ mole $)$ obtained in the present work is smaller than that of Zhao-Karger et al. [1] for the hydrogen release of the commercial $\mathrm{MgH}_{2}(195 \mathrm{~kJ} / \mathrm{mol})$, that of Campostrini et al. [16] for the hydrogen release of the commercial $\mathrm{MgH}_{2}$ powders $(240 \mathrm{~kJ} / \mathrm{mol})$, and that of Figen et al. [3] for the hydrogen desorption of $\mathrm{MgH}_{2}$ synthesized from ball-milled waste magnesium with tetrahydrofuran (THF) $(255 \mathrm{~kJ} / \mathrm{mol})$ or $\mathrm{NaCl}(256 \mathrm{~kJ} / \mathrm{mol})$, but larger than ball-milled $\mathrm{MgH}_{2}[4,5]$. Our result has a value very similar to that of Sabitu et al. [2] for $\mathrm{MgH}_{2}$ decomposition $(174 \mathrm{KJ} / \mathrm{mol})$. 
Table 3. Activation energies of reported Mg-based hydrogen storage materials.

\begin{tabular}{|c|c|c|c|c|c|}
\hline Sample & Composition & Preparation Condition & $\begin{array}{l}\text { Analysis } \\
\text { Method }\end{array}$ & $\begin{array}{c}\text { Activation Energy } \\
(\mathrm{kJ} / \mathrm{mol})\end{array}$ & Reference \\
\hline commercial $\mathrm{MgH}_{2}$ & $\mathrm{MgH}_{2}$ & & $\begin{array}{l}\text { Kissinger } \\
\text { plot }\end{array}$ & 195 & [1] \\
\hline $\begin{array}{l}\text { ball-milled } \mathrm{MgH}_{2} \\
\text { with graphite }\end{array}$ & $\begin{aligned} & 0.3 \mathrm{~g} \mathrm{MgH}_{2} \\
+ & 2 \text { g graphite }\end{aligned}$ & ball milling & $\begin{array}{l}\text { Kissinger } \\
\text { plot }\end{array}$ & 165 & {$[1]$} \\
\hline $\begin{array}{l}\text { infiltrated } \mathrm{MgH}_{2} / \mathrm{ACF} \\
\text { (activated carbon } \\
\text { fiber) composite }\end{array}$ & $\begin{array}{l}0.3 \mathrm{~g} \mathrm{MgH}_{2} \\
+2 \mathrm{~g} \mathrm{ACF}\end{array}$ & infiltration & $\begin{array}{l}\text { Kissinger } \\
\text { plot }\end{array}$ & 143 & [1] \\
\hline $\mathrm{MgH}_{2}$ (without oxide) & $\mathrm{MgH}_{2}$ & & $\begin{array}{l}\text { Kissinger } \\
\text { plot }\end{array}$ & 174 & [2] \\
\hline $\begin{array}{c}\mathrm{MgH}_{2}+4 \mathrm{~mol}^{\%} \\
\mathrm{Nb}_{2} \mathrm{O}_{5}\end{array}$ & $\begin{array}{c}96 \mathrm{~mol} \% \mathrm{MgH}_{2}+4 \\
\mathrm{~mol}_{\%} \mathrm{Nb}_{2} \mathrm{O}_{5}\end{array}$ & ball milling & $\begin{array}{l}\text { Kissinger } \\
\text { plot }\end{array}$ & 95 & [2] \\
\hline $\mathrm{MgH}_{2}+4 \mathrm{~mol} \% \mathrm{Fe}_{3} \mathrm{O}_{4}$ & $\begin{array}{c}96 \mathrm{~mol} \% \mathrm{MgH}_{2}+4 \\
\mathrm{~mol}^{2} \mathrm{Fe}_{3} \mathrm{O}_{4}\end{array}$ & ball milling & $\begin{array}{l}\text { Kissinger } \\
\text { plot }\end{array}$ & 108 & [2] \\
\hline $\mathrm{MgH}_{2}+4 \mathrm{~mol} \% \mathrm{ZrO}_{2}$ & $\begin{array}{c}96 \mathrm{~mol} \% \mathrm{MgH}_{2}+4 \\
\mathrm{~mol}^{2} \mathrm{ZrO}_{2}\end{array}$ & ball milling & $\begin{array}{l}\text { Kissinger } \\
\text { plot }\end{array}$ & 113 & [2] \\
\hline $\mathrm{MgH}_{2}+4 \mathrm{~mol}^{\%} \mathrm{CeO}_{2}$ & $\begin{array}{c}96 \mathrm{~mol} \% \mathrm{MgH}_{2}+4 \\
\mathrm{~mol}_{0} \mathrm{CeO}_{2}\end{array}$ & ball milling & $\begin{array}{l}\text { Kissinger } \\
\text { plot }\end{array}$ & 140 & [2] \\
\hline $\mathrm{MgH}_{2}$ & $\mathrm{MgH}_{2}$ & $\begin{array}{l}\text { ball milling waste } \\
\text { magnesium with } \\
\text { tetrahydrofuran (THF) }\end{array}$ & $\begin{array}{l}\text { Doyle and Kissinger } \\
\text { non-isothermal } \\
\text { kinetic models }\end{array}$ & 255 & {$[3]$} \\
\hline $\mathrm{MgH}_{2}$ & $\mathrm{MgH}_{2}$ & $\begin{array}{l}\text { ball milling waste } \\
\text { magnesium with } \mathrm{NaCl}\end{array}$ & $\begin{array}{l}\text { Doyle and Kissinger } \\
\text { non-isothermal } \\
\text { kinetic models }\end{array}$ & 256 & [3] \\
\hline as-received $\mathrm{MgH}_{2}$ & $\mathrm{MgH}_{2}$ & & $\begin{array}{l}\text { Kissinger } \\
\text { plot }\end{array}$ & 213 & [4] \\
\hline ball-milled $\mathrm{MgH}_{2}$ & $\mathrm{MgH}_{2}$ & ball milling & $\begin{array}{l}\text { Kissinger } \\
\text { plot }\end{array}$ & 138 & [4] \\
\hline $\mathrm{MgH}_{2} / \mathrm{LiCl}$ mixture & & $\begin{array}{l}\text { ball milling after } \\
\text { treatment with } \\
\text { tetrahydrofuran (THF) }\end{array}$ & $\begin{array}{l}\text { Kissinger } \\
\text { plot }\end{array}$ & 115 & {$[4]$} \\
\hline as-milled $\mathrm{MgH}_{2}$ & $\mathrm{MgH}_{2}$ & milling & $\begin{array}{l}\text { Kissinger } \\
\text { plot }\end{array}$ & 142 & {$[5]$} \\
\hline $\mathrm{MgH}_{2}+20 w t \% \mathrm{PdCl}_{2}$ & $\begin{array}{c}80 w \mathrm{w} \% \mathrm{MgH}_{2}+20 \\
\mathrm{wt} \% \mathrm{PdCl}_{2}\end{array}$ & milling with $\mathrm{PdCl}_{2}$ & $\begin{array}{l}\text { Kissinger } \\
\text { plot }\end{array}$ & 99 & [5] \\
\hline commercial $\mathrm{MgH}_{2}$ & $\mathrm{MgH}_{2}$ & & Friedman method & 240 & [16] \\
\hline $\mathrm{Mg}-5 \mathrm{Ni}$ & $\begin{array}{c}95 w t \% M g \\
w t \% ~\end{array}$ & milling in hydrogen & $\begin{array}{l}\text { Kissinger } \\
\text { plot }\end{array}$ & 174 & $\begin{array}{c}\text { this } \\
\text { work }\end{array}$ \\
\hline
\end{tabular}

Because the first-order reaction was assumed for the derivation of the Kissinger equation [6], this equation can be used for some reactions on heating that obey a first-order law. Reaction order should be checked before applying the Kissinger equation. Even in a multi-step reaction, the Kissinger plot may show good linearity in cases when the activation energies are similar in multi-steps. Vyazovkin [17] reported that the Kissinger method should be used under a temperature program of linear heating, never being applied to the data obtained on cooling. This method must be applied to single-step kinetics, not to multi-step kinetics; the method tends to yield a single activation energy even though the process is controlled by more than one energy barrier.

Parameters that would influence the results of activation energy are measuring exact temperature variation of the samples during heating, measuring the time interval to analyze the decomposition rates, and deciding the points of the highest decomposition rates in time-dependent reaction rate curves and time-dependent temperature curves.

It is thought that the application of the Kissinger to the volumetric measurements leads to the less accurate activation energy than that of calorimetric measurements because 
an additional step (obtaining the $\mathrm{d} H / \mathrm{d} t$ versus $t$ curves) is involved, but they are very close. Kissinger [18] reported that the temperatures of maximum reaction rate were very close to the peak temperatures observed in DTA.

Han et al. $[19,20]$ reported that the activation energy for hydride decomposition can be obtained from $\ln \left(b / T^{2}\right)$ versus $1 / T$ plot, where $b$ is the heating rate and $T$ is the temperature. Their equation for this plot was given by

$$
\ln \left(b / T^{2}\right)=\ln (c / E)-E / R T
$$

where $\mathrm{c}$ is a constant, $E$ the activation energy for hydride decomposition, and $R$ the gas constant, and the reacted fraction was assumed to be constant. This plot is very similar to that to obtain the activation energy using the Kissinger equation. They derived the equation based on the continuous moving boundary model, assuming that the particles were spherical with a uniform diameter and that the rate-controlling step for hydride decomposition was an interfacial chemical reaction. They obtained an activation energy for magnesium hydride decomposition of $142 \mathrm{~kJ} / \mathrm{mol}$.

\section{Conclusions}

The quantity of hydrogen released from the sample and the temperature of the reactor were first measured as a function of time at different heating rates $(\Phi)$ in a Sieverts-type apparatus. The dehydriding rates were calculated according to time and the temperature at which the dehydriding rate was the highest $\left(T_{\mathrm{m}}\right)$ was obtained. $\Phi$ and $T_{\mathrm{m}}$ were then applied to the Kissinger equation to determine the activation energy for hydride decomposition. After activation, the $\mathrm{Mg}-5 \mathrm{Ni}$ sample with a composition of $95 \mathrm{wt} \% \mathrm{Mg}+5 \mathrm{wt} \% \mathrm{Ni}$ contained $\mathrm{Mg}$ and $\mathrm{Mg}_{2} \mathrm{Ni}$ that absorbed hydrogen and then released hydrogen during hydridingdehydriding cycling at $593 \mathrm{~K}$. Because the content of $\mathrm{Mg}_{2} \mathrm{Ni}$ was small, most of the hydrogen released from the sample is believed to be from the decomposition of $\mathrm{Mg}$ hydride. The dehydriding rate of the hydrided $\mathrm{Mg}-5 \mathrm{Ni}$ sample obeyed a first-order law. Therefore, the Kissinger equation could be used to determine the activation energy for hydride decomposition of hydrided $\mathrm{Mg}-5 \mathrm{Ni}$. On heating rates of 3,6, 9, 12, and $15 \mathrm{~K} / \mathrm{min}, \mathrm{T}_{\mathrm{m}}$ 's were 590.0, 596.3, 606.3, 612.5, and $613.0 \mathrm{~K}$, respectively. From a plot of $\ln \left(\Phi / T_{\mathrm{m}}{ }^{2}\right)$ versus $1 / T_{\mathrm{m}}$, the obtained activation energy for hydride decomposition was $174 \mathrm{~kJ} / \mathrm{mole}$.

Author Contributions: Conceptualization, M.-Y.S. and Y.-J.K.; methodology M.-Y.S. and Y.-J.K.; formal analysis, M.-Y.S. and Y.-J.K.; investigation, M.-Y.S. and Y.-J.K.; data curation, M.-Y.S. and Y.-J.K.; writing—original draft preparation, M.-Y.S.; writing—review and editing, M.-Y.S. and Y.-J.K.; visualization, Y.-J.K. All authors have read and agreed to the published version of the manuscript.

Funding: This work was supported by the National Research Foundation of Korea (NRF) grant funded by the Korea government (MSIT) (No. 2021R1C1C2009103).

Institutional Review Board Statement: Not applicable.

Informed Consent Statement: Not applicable.

Data Availability Statement: Data presented in this article are available upon request from the corresponding author.

Conflicts of Interest: The authors declare no conflict of interest.

\section{References}

1. Zhao-Karger, Z.; Hu, J.; Roth, A.; Wang, D.; Kubel, C.; Lohstroh, W.; Fichtner, M. Altered thermodynamic and kinetic properties of $\mathrm{MgH}_{2}$ infiltrated in microporous scaffold. Chem. Commun. 2010, 46, 8353-8355. [CrossRef] [PubMed]

2. Sabitu, S.T.; Goudy, A.J. Dehydrogenation kinetics and modeling studies of $\mathrm{MgH}_{2}$ enhanced by transition metal oxide catalysts using constant pressure thermodynamic driving forces. Metals 2012, 2, 219-228. [CrossRef]

3. Figen, A.K.; Coskuner, B.; Piskin, S. Hydrogen desorption kinetics of $\mathrm{MgH}_{2}$ synthesized from modified waste magnesium. Mater. Sci. 2014, 32, 385-390. [CrossRef]

4. Xiao, X.; Liu, Z.; Yarahmadi, S.S.; Gregorya, D.H. Facile preparation of $\beta-/ \gamma-\mathrm{MgH}_{2}$ nanocomposites under mild conditions and pathways to rapid dehydrogenation. Phys. Chem. Chem. Phys. 2016, 18, 10492-10498. [CrossRef] [PubMed] 
5. Mustafa, N.S.; Juahir, N.; Halim Yap, F.A.; Ismail, M. Enhanced hydrogen storage properties of $\mathrm{MgH}_{2}$ by the addition of PdCl Catalyst. Int. J. Electroact. Mater. 2016, 4, 1-7. Available online: https://www.researchgate.net/publication/293820495_Enhanced_ Hydrogen_Storage_Properties_of_MgH_2_by_The_Addition_of_PdCl_2_Catalyst (accessed on 31 December 2021).

6. Blainea, R.L.; Kissinger, H.E. Homer Kissinger and the Kissinger equation. Thermochim. Acta 2012, 540, 1-6. [CrossRef]

7. Bobet, J.-L.; Akiba, E.; Darriet, B. Study of $\mathrm{Mg}-\mathrm{M}(\mathrm{M}=\mathrm{Co}, \mathrm{Ni}$ and $\mathrm{Fe})$ mixture elaborated by reactive mechanical alloying: Hydrogen sorption properties. Int. J. Hydrog. Energy 2001, 26, 493-501. [CrossRef]

8. Santos, S.F.; Ishikawa, T.T.; Botta, W.J.; Huot, J. $\mathrm{MgH}_{2}+$ FeNb nanocomposites for hydrogen storage. Mater. Chem. Phys. 2014, 147, 557-562. [CrossRef]

9. Asselli, A.A.C.; Santos, S.F.; Huot, J. Hydrogen storage in filed magnesium. J. Alloys Compd. 2016, 687, 586-594. [CrossRef]

10. Bobet, J.-L.; Akiba, E.; Nakamura, Y.; Darriet, B. Study of Mg-M (M=Co, Ni and Fe) mixture elaborated by reactive mechanical alloying-hydrogen sorption properties. Int. J. Hydrog. Energy 2000, 25, 987-996. [CrossRef]

11. Song, M.Y.; Kwak, Y.J.; Lee, S.H.; Park, H.R. Enhancement of hydrogen storage characteristics of Mg by addition of nickel and niobium (V) fluoride via mechanical alloying. Korean J. Met. Mater. 2016, 54, 210-216. [CrossRef]

12. Song, M.Y.; Ivanov, E.I.; Darriet, B.; Pezat, M.; Hagenmuller, P. Hydriding properties of a mechanically alloyed mixture with a composition $\mathrm{Mg}_{2}$ Ni. Int. J. Hydrog. Energy 1985, 10, 169-178. [CrossRef]

13. Song, M.Y.; Choi, E.; Kwak, Y.J. Preparation of a Mg-based alloy with a high hydrogen-storage capacity by adding a polymer CMC via milling in a hydrogen atmosphere. Int. J. Hydrog. Energy 2019, 44, 3779-3789. [CrossRef]

14. Song, M.Y.; Choi, E.; Kwak, Y.J. Increase in the dehydrogenation rate of Mg-CMC (Carboxymethylcellulose, Sodium Salt) by adding Ni via hydride-forming milling. Met. Mater. Int. 2019, 25, 516-527. [CrossRef]

15. Song, M.Y; Choi, E.; Kwak, Y.J. Nickel, graphene, and yttria-stabilized zirconia (YSZ)-added Mg by grinding in hydrogen atmosphere for hydrogen storage. Metals 2019, 9, 1347. [CrossRef]

16. Campostrini, R.; Abdellatief, M.; Leoni, M.; Scardi, P. Activation energy in the thermal decomposition of $\mathrm{MgH}_{2}$ powders by coupled TG-MS measurements. J. Therm. Anal. Calorim. 2014, 116, 225-240. [CrossRef]

17. Vyazovkin, S. Kissinger method in kinetics of materials: Things to beware and be aware of. Molecules 2014, 25, 2813. [CrossRef] [PubMed]

18. Kissinger, H.E. Variation of peak temperature with heating rate in differential thermal analysis. J. Res. Natl. Bur. Stand. 1956, 4, 217-221. [CrossRef]

19. Han, J.S.; Pezat, M.; Lee, J.-Y. Thermal desorption of hydrogen from magnesium hydride. Scr. Metall. 1986, 20, 951-956. [CrossRef]

20. Han, J.S.; Pezat, M.; Lee, J.-Y. A study of the decomposition of magnesium hydride by thermal analysis. J. Less-Common Met. 1987, 130, 195-402. [CrossRef] 